\title{
AKTIVITAS FISIK AKUT INTENSITAS TINGGI MEMPERBAIKI KADAR IL-6 OTOT MODEL MENCIT DIABETES MELITUS
}

\author{
Septyaningrum Putri Purwoto'), Bambang Purwanto ${ }^{2)}$, Paulus Liben ${ }^{3)}$ \\ 1),22,3) Departemen Ilmu Faal, Fakultas Kedokteran, Universitas Airlangga Surabaya \\ E-mail: septyaningrumputri29@gmail.com
}

\begin{abstract}
Diabetes mellitus is a metabolic disease whose prevalence continues to increase. Diabetes mellitus sufferers are advised to do lifestyle interventions in the form of physical activity. Physical activity provides benefits for diabetics, through the autocrine response of muscles to release IL-6 for muscle repair. The purpose of this study was to determine the appropriate intensity of physical activity against muscle IL-6 in diabetic mice. The subjects in this study were male mice (balb / c) weighing 20-30 grams. This study was divided into 4 groups. The treatment in the form of treadmill activity is carried out once with heating for 5 minutes and core for 30 minutes. This study used a True Experimental research design using a Random Control Group Posttest-Only Design research design. The variable measured in this study was muscle IL-6, namely the calf muscle (gastrocnemious and soleus muscles) of the left and right legs of each subject 24 hours after acute physical activity. Acute physical activity causes the release of interleukin-6 by myofibers. Based on the analysis results showed that there was a significant effect of low, medium, and high intensity acute physical activity on muscle IL-6 levels $(p=0.05)$. In addition, it also showed that the highest average muscle IL-6 level was the high intensity treatment group with a value of $325.17267 \mathrm{mg} / \mathrm{dL}$. These results prove that bigh-intensity acute physical activity improves IL-6 levels in the muscle muscle model of diabetes mellitus mice.
\end{abstract}

Keywords: Acute physical activity; diabetes mellitus; muscle IL-6.

\begin{abstract}
ABSTRAK
Diabetes melitus merupakan penyakit metabolik yang prevalensinya terus meningkat. Penderita diabetes melitus disarankan melakukan intervensi lifestyle berupa aktifitas fisik. Aktivitas fisik memberikan manfaat untuk penderita diabetes, melalui respon autokrin otot akan melepaskan IL-6 untuk perbaikan otot. Tujuan penelitian ini untuk mengetahui intensitas aktivitas fisik yang tepat terhadap IL-6 ototpada mencit model diabetes. Subyek pada penelitian ini adalah mencit bergalur (balb/c) dengan berat badan 20-30 gram berjenis kelamin jantan. Penelitian ini dibagi menjadi 4 kelompok. Perlakuan berupa aktivitas treadmill dilakukan 1 kali dengan pemanasan selama 5 menit dan inti selama 30
\end{abstract}

Cara mengutip: Purwoto, S., Putri., Purwanto, Bambang \& Liben, Paulus. (2020). Aktivitas Fisik akut intensitas tinggi memperbaiki kadar IL-6 Otot model mencit Diabetes Melitus. Care:Jurnal Ilmiah Ilmu Kesehatan, 8(3), 416-423

Retrieved from https://jurnal.unitri.ac.id/index.php/care/article/view/1299 
menit.Penelitian ini menggunakan desain penelitian TrueExperimental dengan menggunakan rancangan penelitian Random Control Group Posttest-Only Design. Variabel yang diukur dari penelitian ini yaitu IL-6 otot, yaitu pada bagian calf muscle (otot gastrocnemious dan soleus) kaki kiri dan kanan dari masing-masing subyek 24 jam setelah aktivitas fisik akut. Aktivitas fisik akut menyebabkan pelepasan interleukin- 6 oleh myofibers. Berdasarkan hasil analisis menunjukkanterdapat pengaruh yang signifikan aktivitas fisik akut intensitas rendah, sedang, dan tinggi terhadap kadar IL-6 otot $(p=0,05)$. Selain itu juga menunjukkan rerata kadar IL6 otot yang paling tinggi adalah kelompok perlakuan intensitas tinggi dengan nilai $325,17267 \mathrm{mg} / \mathrm{dL}$. Hasil tersebut membuktikan bahwa aktivitas fisik akut intensitas tinggi memperbaiki kadar IL-6 otot model mencit diabetes melitus.

Kata kunci: Aktivitas fisik akut, diabetes mellitus, IL-6 otot

\section{PENDAHULUAN}

Diabetes Melitus

(DM) telah

dikategorikan sebagai penyakit global yang prevalensinya terus meningkat (Harahap et al., 2015). Hal ini ditunjukkan dengan prevalensi kejadian DM di dunia pada tahun 2015 menurut International Diabetes Federation (IDF) mencapai 415 juta jiwa. Bahkan di dunia, Indonesia menempati peringkat ke-7 dengan prevalensi 10 juta jiwa setelah China, India, Amerika Serikat, Brazil, Rusia, Mexico. IDF (2015) telah memprediksi bahwa prevalensi DM diperkirakan akan terus meningkat pada tahun 2040. DM merupakan suatu penyakit metabolik yang mempengaruhi metabolisme karbohidrat, lemak dan protein serta ditandai dengan hiperglikemia. Penderita DM disarankan melakukan intervensi lifestyle berupa aktifitas fisik (Aggarwala et al., 2016). Aktivitas fisik akut menyebabkan pelepasan sitokin. Sitokin yang paling tinggi dilepaskan akibat aktivitas fisik akut yaitu interlenkin-6(IL-6) (Pedersen, 2000). IL-6 yang dilepaskan oleh myofibers akibat aktivitas fisik menyebabkan efek antiinflamasi secara autokrin (Petersen \& Pedersen, 2006).

Aktivitas fisik sangat bermanfaat dalam menjaga kesehatan. Selain sebagai preventif, aktivitas fisik juga dapat digunakan sebagai terapi pendukung terhadap beberapa penyakit degeneratif dan metabolik. Salah satu penyakit metabolik yang insiden dan pravelensinya terus meningkat saat ini adalah DM. Pengetahuan mengenai aktivitas fisik pada penderita DM tidak sepenuhnya dipahami oleh penderita itu sendiri. Hal ini dikarenakan, aktivitas fisik harus disesuaikan dengan keadaan penyakit sehingga tidak menimbulkan resiko yang tidak diinginkan (Sinaga, 2016). Bahkan, aktivitas fisik berpotensi dalam mengurangi beban kesehatan komplikasi diabetes, meliputi nefropati, retinopati, 
neuropati, dan penyakit arteri perifer (Kirwan et al., 2017). Namun, aktivitas fisik pada penderita diabetes harus memperhatikan intensitasnya, hal ini dikarenakan apabila aktivitas fisik dilakukan dengan intensitas yang tepat dapat menjadi stimulator bagi tubuh (Sugiharto, 2012).

Aktivitas fisik merupakan bentuk stresor fisik (Fischer, 2006). Hal ini dikarenakan, aktivitas fisik merupakan kegiatan yang menimbulkan kontraksi otot, terutama pada otot rangka. Kontraksi otot akan menyebabkan kerusakan mikro pada serabut otot rangka. Melalui respon autokrin otot akan melepaskan IL-6 untuk perbaikan otot rangka (Petersen \& Pedersen, 2006). Penelitian oleh Ghazalian et al. (2014) menunjukkan bahwa aktivitas fisik akut intensitas tinggi meningkatkan kadar IL-6. Senada dengan penelitian oleh Sim et al. (2013) menunjukkan peningkatan yang signifikan kadar IL-6 setelah aktivitas fisik akut dengan berbagai intensitas. Akan tetapi, aktivitas fisik akut padaintensitas rendah, sedang, dan tinggi terhadap IL-6 otot masih belum jelas. Oleh karena itu, pada penelitian ini bertujuan untuk membuktikan bagaimana aktivitas fisik akut pada intensitas rendah, sedang, dan tinggi terhadap kadar IL-6 otot.

\section{METODE PENELITIAN}

Subyek pada penelitian ini adalah mencit bergalur $(b a l b / c)$ dengan berat badan 20 30 gram berjenis kelamin jantan. Teknik pengambilan sampel yaitu menggunakan rumus Federer (1977), dan didapatkan sebanyak 28 mencit yang dibagi menjadi 4 kelompok dengan teknik random sampling(kelompok perlakuan intensitas tinggi, kelompok perlakuan intensitas sedang, kelompok perlakuan intensitas rendah, dan kelompok kontrol). Sebelum diberikan perlakuan aktivitas fisik berupatreadmill subyek penelitian diinduksi STZ sebanyak 5 kali dan 3 hari setelahnya di tes GDPP yang diukur dengan glucometer merk EasyTouch, apabila nilainya $\geq 200 \mathrm{mg} / \mathrm{dL}$ berarti sudah diabetes dan siap diberikan perlakuan. Perlakuan berupa aktivitas treadmilldengan sudut $0^{\circ}$ yang dilakukan 1 kali dengan pemanasan selama 5 menit dan inti selama 30 menit, dimulai pukul 10.00 WIB yang terdiri dari kelompok intensitas rendah (kecepatan 14 cm/detik), sedang (kecepatan 21 $\mathrm{cm} /$ detik), dan tinggi (kecepatan 30 $\mathrm{cm} /$ detik), dengan pemanasan selama 5 menit dengan kecepatan $7 \mathrm{~cm} /$ detik dan inti (intensitas rendah, sedang, tinggi). Penelitian ini menggunakan desain penelitian TrueExperimental dengan menggunakan rancangan penelitian 
Random Control Group Posttest-Only Design.

Variabel yang diukur dari penelitian ini yaitu IL-6 otot, yaitu pada bagian calf muscle (otot gastrocnemious dan soleus) kaki kiri dan kanan dari masing-masing subyek 24 jam setelah aktivitas fisik akut.Analisis IL-6 otot dilakukan melalui supernatant otot yang dianalisis menggunakan metode ELISA (Enzime Linked Immunosurbent-Essay).Analisis data pada penelitan ini menggunakan aplikasi SPSS 22, meliputi uji normalitashomogenitas, uji anova, dan uji brown forsythe.

\section{HASIL}

\section{Rerata Kadar IL-6 Otot}

Berdasarkan hasil analisis data penelitian rerata kadar IL-6 otot menunjukkan bahwa rerata (mean) kadar IL-6 otot kelompok intensitas sedang $<$ intensitas rendah $<$ kontrol $<$ intensitas tinggi. Pada gambar 1 menunjukkan rerata kadar IL-6 otot yang paling tinggi adalah kelompok perlakuan intensitas tinggi dengan nilai $325,17267 \mathrm{mg} / \mathrm{dL}$, sedangkan rerata kadar IL-6 otot yang paling rendah adalah kelompok intensitas sedang dengan nilai 97,889 mg/dL. Pada kelompok intensitas rendah kadar IL-6 otot menunjukkan nilai 149,926 mg/dL, dan pada kelompok kontrol yaitu dengan nilai 187,58017 $\mathrm{mg} / \mathrm{dL}$.

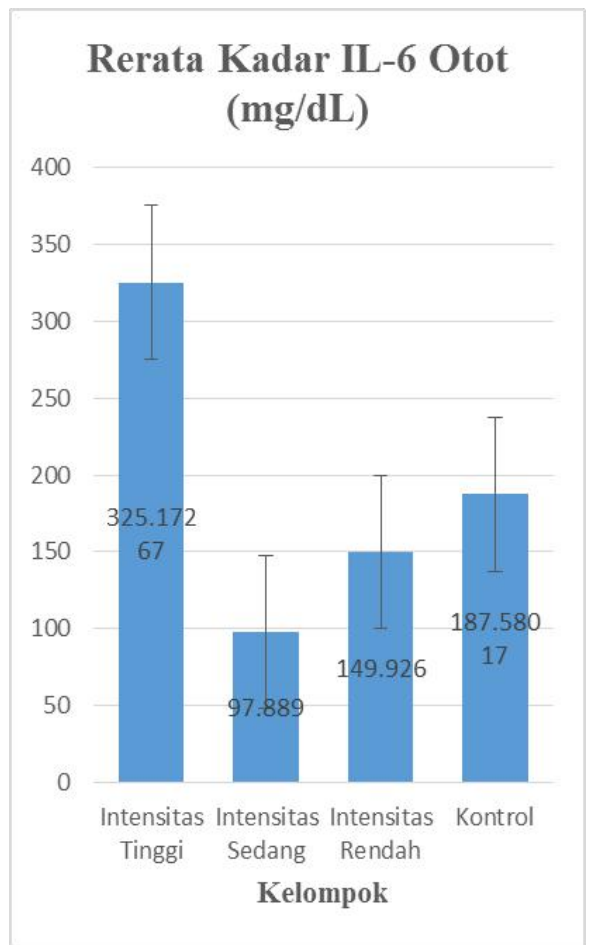

Gambar 1. Rerata Kadar IL-6 Otot (Purwoto, 2019)

Untuk mengetahui pengaruh akut perbedaan intensitas aktivitas fisik treadmill menggunakan uji anova, namun pada kadar IL-6 otot pada didaparkan data tidak homogen sehingga setelah uji anova dilanjutkan dengan uji Brown Forsythe. Berdasarkan hasil analisis menunjukkan ada pengaruh yang signifikan aktivitas fisik akut intensitas rendah, sedang, dan tinggi terhadap kadar IL-6 otot $(p=0,05)$. Data kadar IL-6 otot bisa dilihat pada tabel 1 . 
Tabel 1. Analisis Kadar IL-6 Otot (Purwoto, 2019)

\begin{tabular}{|c|c|c|c|c|c|c|}
\hline Groups & $\mathbf{N}$ & Mean \pm SD & $\begin{array}{c}\text { Normality } \\
\text { Test }\end{array}$ & $\begin{array}{c}\text { Homogenity } \\
\text { Test }\end{array}$ & P Anova & $\begin{array}{l}\text { P Brown } \\
\text { Forsythe }\end{array}$ \\
\hline $\begin{array}{l}\text { Intensitas } \\
\text { Tinggi }\end{array}$ & 6 & $\begin{array}{l}325,17267 \pm 1 \\
09,158218\end{array}$ & 0,166 & & & \\
\hline $\begin{array}{l}\text { Intensitas } \\
\text { Sedang }\end{array}$ & 6 & $\begin{array}{l}97,88900 \pm 32 \\
087884\end{array}$ & 0,904 & $0,003^{*}$ & 0,000 & 0,002 \\
\hline $\begin{array}{l}\text { Intensitas } \\
\text { Rendah }\end{array}$ & 6 & $\begin{array}{l}149,92600 \pm 2 \\
9,021247\end{array}$ & 0,639 & & & \\
\hline Kontrol & 6 & $\begin{array}{l}187,58017 \pm 1 \\
0,544678\end{array}$ & 0,555 & & & \\
\hline
\end{tabular}

\section{Keterangan}

* : Tidak homogen

\section{PEMBAHASAN}

Berdasarkan hasil dari penelitian ini menunjukkan bahwa ada perbedaan pengaruh yang signifikan intensitas aktivitas akut treadmill terhadap kadar IL-6 otot model mencit diabetes melitus (tabel 1). Hal ini dikarenakan, aktivitas fisik dan DM melibatkan pensinyalan IL-6 pada otot (Pattamaprapanont et al., 2016). IL-6 merupakan sitokin yang disekresi oleh otot yang berkontraksi selama aktivitas fisik yang tergantung pada intensitas dan durasi yang dilakukan (Morettin et al., 2017).

Pada penelitian ini menunjukkan kadar IL-6 otot yang paling tinggi adalah pada kelompok perlakuan intensitas tinggi. Hal ini kemungkinan disebabkan oleh kontraksi otot yang lebih tinggi pada aktivitas akut treadmill intensitas tinggi. Karena ketika kebutuhan energi meningkat menyebabkan otot untuk bekerja lebih keras dalam memasok energy (Melinda, 2004). Pemenuhan kebutuhan energi selama aktivitas fisik meningkatkan kontraksi otot yang ditandai dengan sekresi IL-6. Peningkatan IL-6 akan mengaktivasi GLUT 4 melalui Aktivasi LKB1 (serine/threonine protein kinase 11)/AMPK (activated proteinkinase) /AS160 (protein kinase $B$ substrate of $160 \mathrm{kDa}$ ), hal ini menyebabkan peningkatan ambilan glukosa sehingga terjadi penurunan kadar glukosa darah (Thent et al., 2013; Vasques et al., 2008). 
IL-6 yang disekresi otot juga untuk membantu mempertahankan homeostasis metabolik (Febbraio \& Pedersen, 2002) yang berperan dalam pengaturan metabolisme pada jaringan adiposa, otot rangka dan hati (Lutoztawka, 2012). Pada jaringan adiposa dan hati berkontribusi untuk pemeliharaan homeostasis glukosa, menginduksi lipolisis, dan menghambat efek sitokin pro inflamasi seperti TNF- $\alpha$, sehingga melindungi terhadap resistensi insulin dan aterosklerosis (Pedersen et al., 2001).Keterkaitan IL-6 dengan insulin selama olahraga, dari kontraksi otot selama aktivitas fisik adalah pesan untuk produksi glukosa hepatik. Dengan demikian akan meningkatkan konsumsi subster otot dan meningkatkan glikogen dan oksidasi lemak, sehingga mengaktifkan lipolisis di jaringan adiposa selama aktivitas fisik (Yazdani et al., 2013). Aktivasi lipolisis jaringan lemak untuk memberikan energi ke otot, tetapi juga berpengaruh positif terhadap pemanfaatan lemak intramuskular. Selain ituIL-6 juga menstimulasi satelit sel dan hipertrofi otot serta perbaikan otot (Lutoslawska, 2012), karena merupakan molekul penting hipertrofi otot dengan mengendalikan proliferasi satelit sel dan akresi myonuklear yang dimediasi oleh aktivasi STAT3, sintesis glikogen melalui phosphatidylinositol (PI) 3-kinase (Serrano et al., 2013). Selain itu IL-6 juga dapat mempengaruhi metabolisme lipidmelalui mekanisme MAPK di otot rangka (AlKhalili et al., 2006).

\section{KESIMPULAN}

Terbukti bahwa aktivitas fisik akut pada intensitas rendah, sedang, dan tinggi berpengaruh signifikan terhadap kadar IL-6 otot. Manfaat yang diperoleh pada penelitian ini yaitu dapat dijadikan rekomendasi intensitas aktivitas fisik yang tepat sehingga kadar IL-6 bisa meningkat untuk penderita diabetes. Hal ini dikarenakan, pada penelitian ini terbukti bahwa aktivitas fisik akut intensitas tinggi memperbaiki kadar IL-6 otot model mencit diabetes melitus. Untuk penelitian selanjutnya disarankan berupa aktivitas fisik kronis.

\section{UCAPAN TERIMAKASIH}

Saya mengucapkan terima kasih kepada Allah SWT atas semua rahmatnya. Terima kasih saya ucapkan untuk Dokter Bambang dan almarhum Prof. Paulus yang senantiasa membimbing saya. Tidak lupa saya ucapkan terima kasih kepada ibu saya Ibu Umarsiyah, almarhum Bapak Purwoto, Ramadhan Harum, dan 3 Serangkai yang senantiasa mendo'akan dan mendukung saya. 


\section{REFERENSI}

Aggarwala, J., et al. (2016). Effect of Aerobic Exercise on Blood Glucose Levels and Lipid Profile in Diabetes Mellitus Type 2 Subjects. Al Ameen J Med, 9(1): 65-69.

Al-Khalili, et al. (2006). Signaling Specificity of Interleukin-6 Action on Glucose and Lipid Metabolism in Skeletal Muscle.Molecular Endocrinology, 20 (12): $3364 \quad 337$.

Febbraio, M. \& Pedersen, B. (2002). Muscle derived Interleukin-6: Mechanisms for Activation and Possible BiologicalRoles.The FASEB Journal. 3: 1335 1347.

Fischer, C. P. (2006). Interleukin-6 in Acute Exercise and Training: What Is The Biological

Relevance. Exercise Immunol

Rev, 12: 6-33. Fitness:

Definitions and Distinctions for Health-Related Research. Public Health Reports. 100 (2): 126-130.

Ghazalian, F., et al. (2014). Effect of Acute High Intensity Exercise in Hypoxic Conditions on Plasma IL6, IL-1 ra in Male Wistar Rat. International Journal of Sport Studies, 4(7):818 822.

Harahap, A. S., et al. (2015). Gambaran Glukosa Darah Setelah Latihan Fisik pada Tikus Wistar Diabetes Melitus yang Diinduksi Aloksan. Jurnal Kesehatan Andalas, 4(1): 23-29.

IDF. 2015. Idf Diabetes Atlas Sixth Edition. Diakses pada tanggal 20 Februari 2019 darihttp://www.idf.org/sites/de ault files/Atlas-poster 2015_EN.pdf.

Kirwan, J.P., et al. (2017). The Essential Role of Exercise in The Managament of Type 2
Diabetes. Cleveland and Clinic Journal of Medicine, 84(1): S15-S21.

Lutoslawska, Grazina. 2012. Interleukin-6 as an Adipokine and Myokine: The Regulatory Role of Cytokine in Adipose

Tissue and Skeletal Muscle Metabolism. Human Movement, 13 (4): $\quad 372-379$.

Melinda, M. M. (2004). Nutrition and Physical Activity: Fueling the ActiveIndividual. President's Council on Physical Fitness and Sports ResearchDigest, 5 (2): 1-8.

Morettini, et al. (2017). A system model of the effects of exercise on plasma Interleukin-6 dynamics in healthy individuals: Role of skeletal muscle and adiposetissue. PLOS One, July.

Pattamaprapanont, P., et al. (2016). Effect of Exercise Training on Signaling of Interleukin-6 in Skeletal Muscles of Type 2 Diabetic Rats. The Review of Diabetic Studies, 13(2-3): 197-206.

Pedersen, B. K. (2000). Exercise and cytokines. Immunology and Cell Biology, 78: 532-535.

Pedersen, et al. (2001). Muscle-derived Interleukin-6: Possible Biological Effects. Journal of Physiology. 536 (2):329-337.

Petersen, A.M.W. \& Pedersen, B.K. (2006). The Role of IL-6 in Mediating The Anti

Inflammatory Effects of Exercise. Journal of Physiology and Pharmacology, $57 \quad$ (10): 4351.

Sim, M., et al. (2013). Effect of Exercise Modality and Intensity on Post exercise Interleukin-6 and Hepcidin Levels. International Journal of Sport Nutrition and Exercise Metabolism, 23:178-186.

Sinaga, R.N. 2016. Diabetes Melitus Dan Olahraga. 15(2): 21-29. 
Serrano, A. L., et al. (2008). Interleukin-6

Is an Essential Regulator of Satellite Cell Mediated Skeletal Muscle Hypertrophy. Elsevier Inc, $7(-)$ : 33-44.

Sugiharto. 2012. Fisioneurohormonal Pada Stresor Olahraga. Jurnal Sains Psikologi, 2(2): 54-66.

Thent, Z.C., et al. (2013). Exercise and Type 2 Diabetes Mellitus PLOS ONE, 8(1): 17.

Vasquez, I.N., et al. (2008). Dual Role of Interleukin-6 in Regulating

Insulin Sensitivity in Murine Skeletal Muscle.Diabetes, 57: 3211-3221.

Yazdani, Behrooz, et al. (2013). Determine Changes of Plasma Glucose of Trained and Untrained Male Rats After Eight Week Endurance Exercise. European Journal of Experimental Biology, 2013, 3 (3):267-272. 